\title{
The glycerol biorefinery: a purpose for Brazilian biodiesel production
}

\author{
Emerson Léo Schultz , Daniela Tatiane de Souza and Mônica Caramez Triches Damaso
}

\begin{abstract}
According to estimates from the International Energy Agency, global energy consumption will increase by at least one third, between 2010 and 2035. The additional power required will be provided not only by fossil sources but also by renewables. While the world energy matrix is supplied only by $13.2 \%$ from renewable sources, Brazil has different scenery with renewables accounting for $42.4 \%$ of the energy matrix. This work aimed to evaluate the potential use of oleaginous in biorefineries considering the produced quantity, prices, and costs of raw materials and products. Considering the availability of these raw materials, the results showed significant opportunities that can be exploited in Brazil, within the biorefinery concept. Soybean oil is the main raw material for biodiesel production in Brazil, although there are many other vegetable oils with potential for this purpose. Related to the production costs, the soybean biodiesel has higher costs than diesel. Then, this biofuel is only produced due to Brazilian regulatory rules and public subsidies. In order to become this production favorable in the market environment, it is essential to aggregate value to all byproducts and residues generated along the biodiesel production chain. Glycerin is a byproduct of biodiesel that could be used, in a glycerol biorefinery concept, as raw material for the production of value-added products through chemical, biochemical, or thermochemical routes.
\end{abstract}

Keywords: Biorefinery; Oleaginous; Soybean; Biodiesel; Glycerin; Biofuels; Chemicals; Energy; Prices and costs

\section{Introduction}

Nowadays, most of the energy consumed in the world comes from non-renewable sources, such as petroleum, coal, and natural gas. The world energy matrix uses only $13.2 \%$ from renewable sources, while the Brazilian scenario differs from this context using $42.4 \%$ of these sources, according to 2012 statistical data. They are represented mainly by sugarcane biomass (15.4\%), hydraulic and electric (13.8\%), natural gas (11.5\%), and firewood and charcoal (9.1\%). The participation of renewable sources in the energetic matrix is among the highest in the world, although there has been a slight reduction (1.8\%) from 2011 to 2012, due to lower supply of hydropower and ethanol [1].

Factors such as Brazil's vast territory and favorable weather conditions expand the possibility of using water and biomass for energy production. Among the biomasses, the main are sugarcane, oilseeds, and lignocellulosic materials (e. g., crop residues and wood chips). Notwithstanding, many Brazilian industrial sectors that use biomass as the

\footnotetext{
* Correspondence: emerson.schultz@embrapa.br

Embrapa Agroenergy, Parque Estação Biológica, PqEB s/n - Av.W3 Norte (final), 70770-901 Brasília, DF, Brazil
}

\section{黑 Springer}

(C) 2014 Schultz et al.; licensee Springer. This is an Open Access article distributed under the terms of the Creative Commons Attribution License (http://creativecommons.org/licenses/by/4.0), which permits unrestricted use, distribution, and reproduction in any medium, provided the original work is properly credited. main raw material have envisioned its use not only to produce energy, but in a wider perspective using the concept of biorefinery. For these sectors, the application of this concept is a great opportunity for growth and market expansion.

A biorefinery is a facility that integrates biomass conversion processes and equipment to produce fuels, power, and chemicals [2]. A biorefinery is not a completely new concept. Many of the traditional biomass converting technologies such as sugar, starch, and pulp and paper industries use aspects connected with this approach. However, several economic and environmental drivers such as global warming, security of supply, energy supply, high energy costs, and agricultural policies have also directed those industries to further evolve their operations into biorefineries [3].

The combinations involving raw materials, conversion/ technology processes, and final products are almost unlimited in the biorefinery concept. The final decision about what product will be prioritized in a biorefinery (biofuels, chemicals, or bioenergy) will depend on the availability of raw materials, technological knowledge, public policies, regulations, and market dynamics. 
Considering the availability of raw materials and favorable conditions of price and costs, Brazil has significant opportunities that can be exploited in the biorefinery concept. Thus, this work aimed to present the overview of the Brazilian biodiesel production and the perspective of glycerin use in the biorefinery context.

\section{Review}

\section{Raw materials for biodiesel production}

In 2004, due to the necessity to expand the supply of energy from biomass, the Brazilian Government introduced biodiesel in the national energy matrix, through the National Program for Production and Use of Biodiesel [4]. In 2005, was established optional addition of $2 \%$ biodiesel to petroleum diesel (named B2), which became mandatory from January 2008. This percentage was increased successively by the National Energy Council (CNPE) up to $5 \%$ (B5) in January 2010.

In Brazil, currently, there are 64 biodiesel plants authorized for operation by the Brazilian National Agency of Petroleum, Natural Gas and Biofuels (ANP), with a total production capacity of 7 million $\mathrm{m}^{3} /$ year [5]. In 2012, more than 2.5 million $\mathrm{m}^{3}$ of biodiesel were produced [6], which corresponds to $36 \%$ of the current installed capacity. This production placed Brazil in the third position in the world ranking of biodiesel producers.

The main commercial route used in the biodiesel production is the transesterification process of vegetable oils and fats with alcohols, in the presence of a basic catalyst. This reaction results in three molecules of fatty acid monoalkyl esters, which compose the biodiesel, and one molecule of glycerol or glycerin (byproduct) [7].

In Brazil, there are more than 200 species of plants like fruits and grains that can produce oil, with different potentialities and natural adaptations to environmental conditions, which can be used to produce biofuels or other value-added products [8], but only some of them have been used for biodiesel production. Data on production of oilseeds and fat used for this purpose are shown in Table 1.

Figure 1 presents the contribution of each oil source used for Brazilian biodiesel production in April 2013.
The soybean is the main raw material used. Most of the national soybean production (about 44\%) is exported in the form of grain, $7 \%$ is stocked, and $49 \%$ is processed domestically for obtaining $79 \%$ of soybean meal and $21 \%$ of oil. Seventy-seven percent of this oil is used for food and biodiesel production [12]. In April 2013, the soybean oil used for biofuel production represents more than 2.0 million $\mathrm{m}^{3}$ [13]. The soybean is the main raw material for biodiesel production as a consequence of some important issues, such as technological domain of the crop, scale of production, and the success in establishing the productive chain across the country [8].

Figure 2 displays the growth in the use of the main sources of oils for biodiesel production. Although the role of soybean oil in the biodiesel production is really the most important, the use of fat in this matrix has increased substantially, probably, because it is a residue and its cost is lower than oilseeds. The main barrier for the expansion of fat in biodiesel matrix is the high number of saturated fat acids present in this material.

There is an expectation that the regulatory framework will be increased to B10 by the Brazilian Government. If this actually occurs, it will be urgent to increase the raw material supply through the diversification in the production of oilseed crops in various regions of the country.

\section{Prices and costs of soybean biodiesel}

The price of biodiesel depends greatly on the price of soybean oil in Brazil. In Figure 3, it can be seen that there is a strong correlation between the nominal prices of biodiesel, practiced in the auctions of the National Petroleum Agency (ANP), and the prices of soybean oil. The correlation found between these two variables in the period of January 2011 to November 2013 was 0.73. The National Petroleum Agency uses it largely in the price of soybean oil for pricing in auctions.

With the launch of the National Biodiesel Program (PNPB) establishing the mandatory blending and the scheduled increase in the proportion of biodiesel in fossil diesel, there was a consolidation of the biodiesel market in Brazil. The growth of investments in the structure of

Table 1 Brazilian production of oilseeds and bovine fat in 2011 [9-11]

\begin{tabular}{|c|c|c|c|c|}
\hline Product & Harvested area (ha) & Production (tonnes) & Oil production $\left(\mathrm{kg} \mathrm{ha}^{-1}\right)$ & Main producing state \\
\hline Soybean & $23,968,663$ & $74,815,447$ & 540 & Mato Grosso \\
\hline Cottonseed & $1,405,135$ & $5,070,717$ & 360 & Mato Grosso \\
\hline Palm (bunch) & 109,080 & 1,301,192 & 4,000 & Pará \\
\hline Bovine fat & $\mathrm{Na}$ & 750,000 & $\mathrm{Na}$ & São Paulo \\
\hline Peanut & 106,679 & 311,459 & 800 & São Paulo \\
\hline Castor beans (berry) & 208,476 & 120,166 & 705 & Bahia \\
\hline Sunflower & 62,535 & 77,932 & 630 & Mato Grosso \\
\hline Canola $^{a}$ & 42,400 & 52,000 & 500 & Rio Grande do Sul \\
\hline
\end{tabular}

$\mathrm{Na}$, not applicable. ${ }^{\mathrm{P}}$ Production refers to the $2011 / 2012$ season and not the calendar year. 


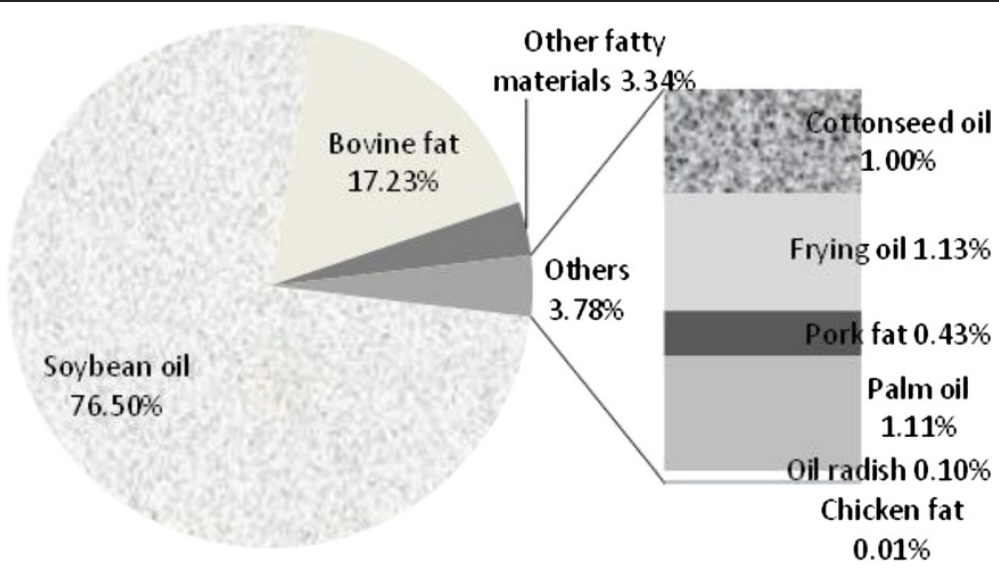

Figure 1 Raw materials used in the production of biodiesel (B100) in Brazil: April 2013 [13].

production of biodiesel allowed for an increase to $5 \%$ blending with 3 years in advance. Achieving this goal has been attributed to the ability of the industry to meet the market needs, as well as the will of the Brazilian Government in the growth of the use of this energy source [17].

The price of biodiesel in the country is set at auctions and it is fixed for a period of 3 months. On the other hand, the soybean oil is a commodity and its price is set by the market. As with other agricultural commodities, after 2002, there was a rise in the price of soybean oil, a fact that reduced substantially the margins of biodiesel processing plants. More recently, there was a fall in the price of soybean oil, reaching US\$0.99/L in November 2013 [16]. This fall has been attributed to the high amount of soybean harvested in Brazil, which has enhanced the availability of raw material for biofuel production. Moreover, the decline is also attributed to the worldwide availability of vegetable oils and excess capacity of the biodiesel facilities in the country (next to 60\%) [18].

Thus, there was a drop in sales prices of B100 at auctions in 2013. The average price of biodiesel in the ANP auctions in 2013 was US $\$ 0.90 / \mathrm{L}$, well below the price established in October 2012 (US\$1.16/L). Even with this

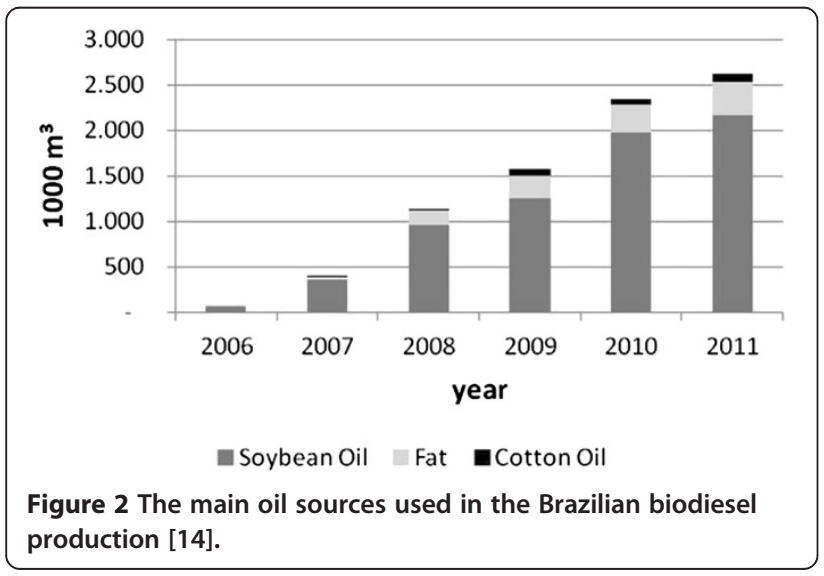

drop in current prices and reduced profit margins, other factors allow the plants to continue to produce biodiesel and expand its production capacity as the growth potential in underexplored markets is high [17].

Table 2 shows the prices and production costs of diesel and biodiesel. In 2013, the average selling price of diesel in the distributor was US\$0.88/L [15]. As transport costs, profit margins, and taxes account for $70 \%$ of this value [19], it is estimated that US $\$ 0.26 / \mathrm{L}$ corresponds to the production cost of diesel.

Different authors estimate different cost of biodiesel production in Brazil $[19,20]$. These costs undoubtedly vary according to the production process as well as the raw material. The cost of soybean biodiesel can reach values between US\$0.63/L and US\$1.25/L, excluding taxes, shipping, and producer profit margin. This value is well above the values of the production cost of diesel (US $\$ 0.26 / \mathrm{L})$.

The high cost of biodiesel production by alkaline transesterification is bound mainly to the high cost of soybean oil, which corresponds to $77 \%$ of total manufacturing costs [20]. Soybean is considered the main source of raw material with enough availability to meet the demand for biodiesel in the country.

\section{Challenges and opportunities within the concept of glycerol biorefinery}

It is estimated that $90 \mathrm{~m}^{3}$ of biodiesel produced by transesterification generates approximately $10 \mathrm{~m}^{3}$ of glycerin. Figure 4 shows the increase of glycerin production which follows the biodiesel production growth in the period from 2005 to 2011. If the use of B10 is implemented in Brazil, 5.56 million $\mathrm{m}^{3}$ biodiesel would be produced, corresponding to approximately $600,000 \mathrm{~m}^{3}$ of glycerin, which is much higher than the national demand. Furthermore, glycerin has a low market value.

The increasing production of glycerin is not only a Brazilian reality; other countries such as the USA [21] 


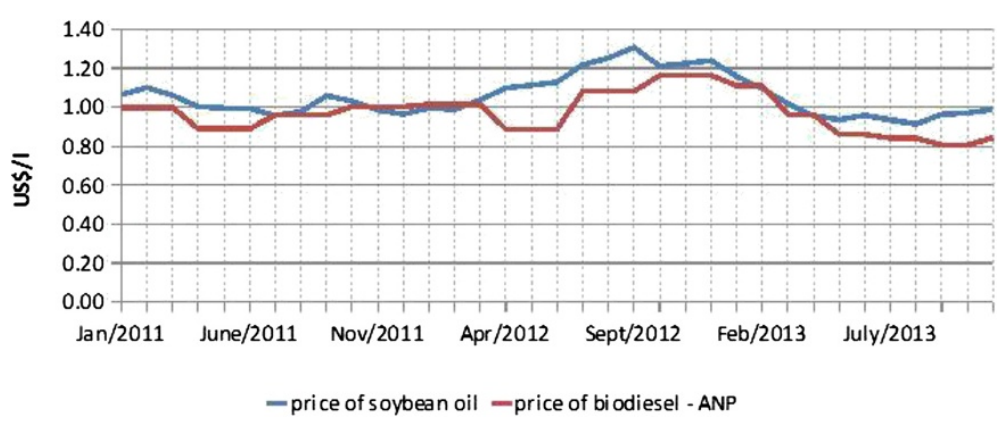

Figure 3 Evolution of biodiesel prices in the ANP auctions and the prices of crude soybean oil (quotation = R\$2.30/US\$). Source: author's calculations based on [15] and [16].

and Germany also have growth in the production of crude glycerin, which is directly related to the increase in the production of biodiesel.

In addition to the excessive amount of glycerin produced, another important issue is the quality of this material. As the main production process of biodiesel is a chemical route using basic catalysts, crude glycerin contains diverse impurities such as alcohol, traces of the catalyst, esters, and salts that hinder its direct application in several industrial processes. Nowadays, the main industrial sectors that consume glycerin worldwide are cosmetics, soaps, and pharmaceuticals $[22,23]$ that require glycerin with certain degree of purity. The purification of crude glycerin obtained from biodiesel production to transform it into analytical grade is not economically favorable for sectors that work with lower value-added products [24].

The crude glycerin produced in Brazil is mostly used to generate heat by burning it in industrial furnaces and boilers, as in biofuel production, besides potteries and steel companies. Also, Brazilian glycerin has been exported to China [25].

Brazil exported 16,400 tonnes of glycerin with revenue of US $\$ 5.4$ million, equivalent to US $\$ 0.30 / \mathrm{kg}$ of glycerin [26]. However, exports of glycerin decreased more than

Table 2 Comparison of prices and costs of diesel and soybean biodiesel $[15,19,20]$

\begin{tabular}{lc}
\hline Description & $\begin{array}{c}\text { Price/cost as of } \\
\mathbf{2 0 1 3} \text { (US\$/L) }\end{array}$ \\
\hline Price of diesel in the refinery [15] & 0.69 \\
Price of diesel in the distribution [15] & 0.89 \\
$\begin{array}{l}\text { Production cost of diesel (estimated in this } \\
\text { paper) }\end{array}$ & 0.26 \\
Average price of biodiesel [15] & 0.90 \\
Cost of biodiesel production (alkaline & 0.63 \\
transesterification with a residual oil from the & \\
pre-treatment step of oil) [20] & \\
Cost of biodiesel production [19] & 0.65 \\
Cost of biodiesel production (conventional & 1.25 \\
alkaline transesterification) [20] & \\
\hline
\end{tabular}

45\% in March of 2013 [27], resulting in a large accumulation of this byproduct in biodiesel plants.

Since there is a global trend of continuing increase in the consumption of biodiesel, it is necessary to search for different technological solutions for crude glycerin in order to add value to the productive chain of biodiesel within the biorefinery concept. Similarly to the sugarcane biorefinery, it has been proposed for glycerol biorefinery [28]. Glycerin may be used as raw material for the production of value-added products through chemical, biochemical, or thermochemical routes, as shown in Figure 5 [23,24,28-32].

Currently, another interesting solution can be to apply crude glycerin from vegetable oil biodiesel production as raw material for animal feed. Some reported data indicate that the use of $10 \%$ crude glycerin as a pig and catfish complement feed maintains their growth with normal performance [30].

Ethanol, hydrogen, and syngas could be used directly as fuels or as intermediates in chemical synthesis. Chemical compounds as polyols and organic acids are very important as building blocks. They are used in industrial sectors such as cosmetic, pharmaceutical, automobile, and chemical industries [33].

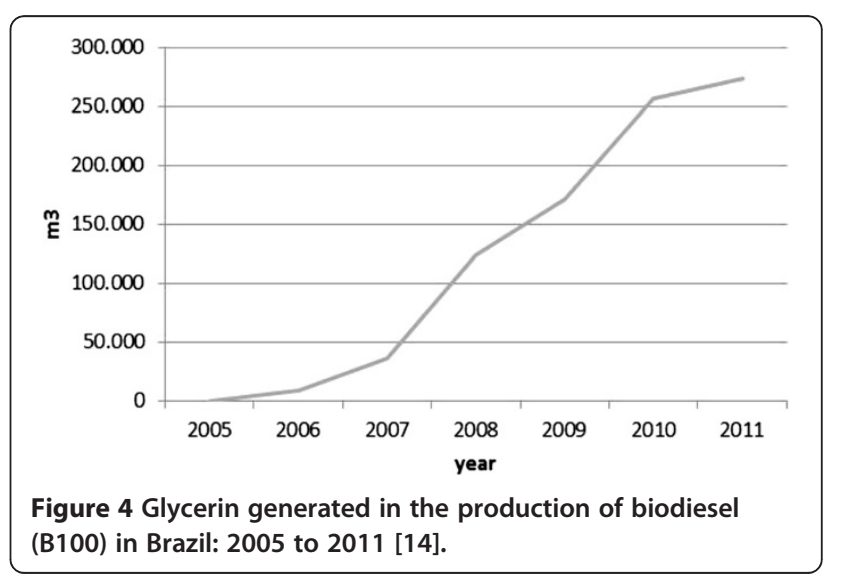




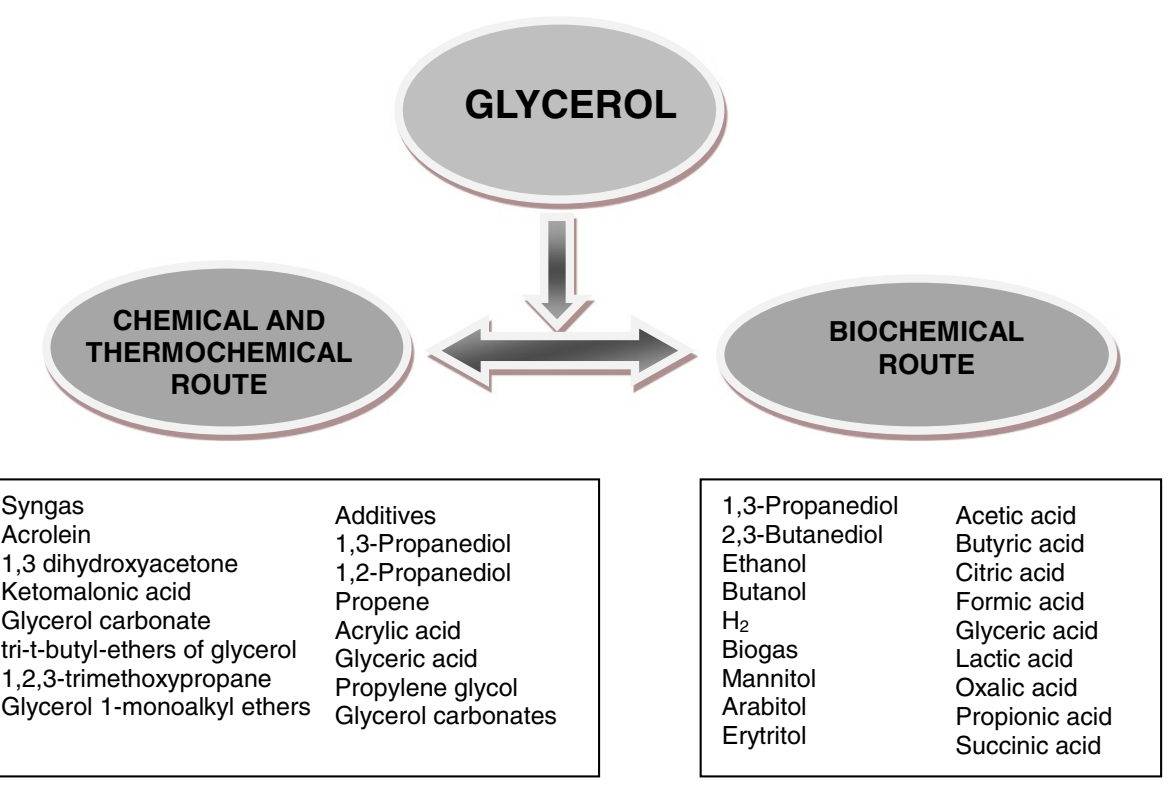

Figure 5 Products obtained from glycerin produced in biorefinery [23,24,28-32].

Glyceric acid may be used in chemical and pharmaceutical industries as a building block and for the production of polymers and surfactants. Lactic acid can be processed to make acrylic acid or 1,2-propanediol used in polyester resins and polyurethane. Succinic acid is largely used for manufacturing health-related products and as building block to produce precursors that are converted into green solvents, pharmaceutical products, and biodegradable plastics. Polyols are used in food, pharmaceutical, and medical industries. They are used to improve the nutritional profile of food products due to their low caloric content, low insulin-mediated response, and non-cariogenicity. Polyols and their derivatives also have other industrial applications, including the production of polyurethanes, plastifying agents, resins, surfactants, and intermediates for producing hydrocarbons [23,24,28-33].

The chemical routes used to transform glycerin include selective oxidation, etherification, dehydration, hydrogenolysis, and reforming [23,34-37]. In the selective oxidation, the oxidation of primary hydroxyl groups yields glyceric acid and tartronic acid, both of which are commercially useful compounds. Dihydroxyacetone (DHA), an important fine chemical, is obtained from the oxidation of the secondary hydroxyl groups, while ketomalonic (or mesoxalic) acid results when all three hydroxyl groups are oxidized [34,38].

Alkyl ethers can be synthesized by the reaction of glycerol with alkenes and preferentially with isobutylene in the presence of an acid catalyst. Ether derivatives of glycerol reduce emissions of particulate matter, hydrocarbons, carbon monoxide, and aldehydes, when incorporated in standard diesel fuel containing $30 \%$ to $40 \%$ of aromatic compounds [34,39].

Dehydration of glycerol may follow two pathways. The dehydration of the secondary hydroxyl group yields 3hydroxypropanal, which undergoes a dehydration step, leading to the formation of acrolein. On the other hand, the dehydration of the primary hydroxyl group results in 1-hydroxyacetone, also known as acetol [23].

Hydrogenolysis is a catalytic chemical reaction that breaks a chemical bond in an organic molecule with the simultaneous addition of a hydrogen atom to result in molecular fragments. Propylene glycol (1,2-propanediol (1,2-PD)) and 1,3-propanediol (1,3-PD) could be obtained through the hydrogenolysis of glycerol in the presence of metallic catalysts and hydrogen $[23,36]$.

One promising way is to use glycerin to produce synthesis gas via steam reforming [40]. Overall, glycerin steam reforming can be represented by the following reaction [37]:

$$
\mathrm{C}_{3} \mathrm{H}_{8} \mathrm{O}_{3}+\mathrm{H}_{2} \mathrm{O} \rightarrow 3 \mathrm{CO}_{2}+7 \mathrm{H}_{2}
$$

Another process used to produce synthesis gas from glycerol is the aqueous phase reforming (APR), using aqueous solutions of glycerol and a catalyst [41]. Synthesis gas can be used to produce hydrocarbons (through Fischer-Tropsch synthesis), methanol, hydrogen, isobutene, and isobutane [42]. BioMCN has been producing methanol from synthesis gas obtained from glycerin since 2010 in Delfzijl (Netherlands) [35]. 
One process widely known for the valorization of glycerin is the synthesis of epichlorohydrin. This chemical is employed in the production of epoxy resins. Advanced Biochemical (Thailand) Co., a subsidiary of Vinythai (shareholders are Solvay and PTT), is producing 100,000 t/year of epichlorohydrin in Thailand (Map Ta Phut) using Solvay technology $\left(\right.$ Epicerol $\left.^{\circ}\right)$. A new plant of Vinythai in China (Taixing) should become operational in the second half of 2014, also with capacity of 100,000 t/year and using the Epicerol ${ }^{\circ}$ technology. In this process, glycerol reacts with $\mathrm{HCl}$, yielding a mixture of 1,2-dichloro-3-propanol and 1,3-dichloro-2-propanol, which is treated with $\mathrm{NaOH}$ resulting in epichlorohydrin. The Dow Chemical Co. and Spolchemie (Czech Republic) have also developed processes to convert glycerin to epichlorohydrin $[23,34,35,43-45]$.

Figure 6 shows some products and their intermediates obtained by biotechnological pathway of glycerol (glycerin) conversion.

The route of biotechnological valorization of glycerol can follow three different pathways. Yeast and filamentous fungi convert glycerol to polyols and organic acids by

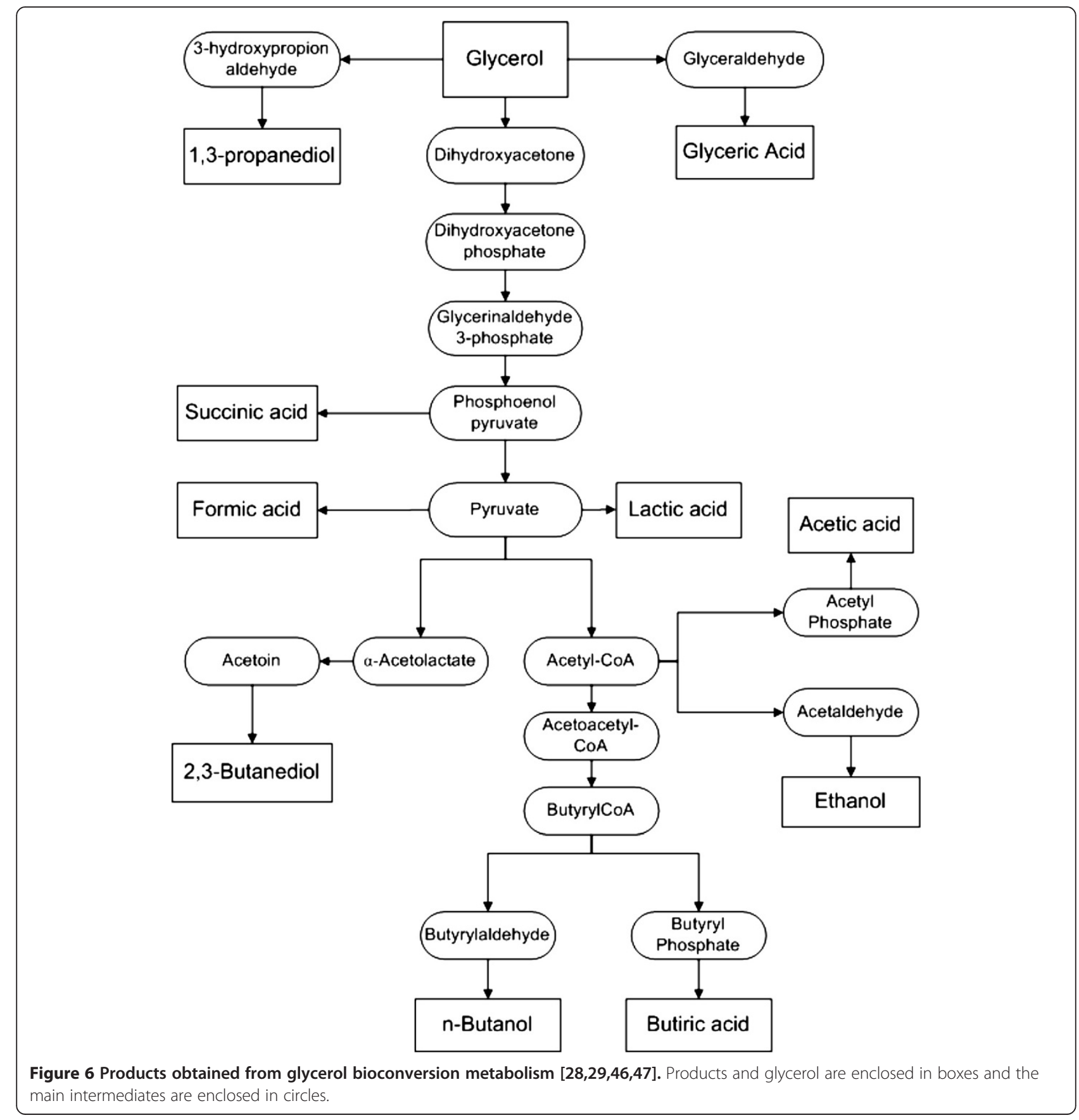


aerobic process. Enterobacteriaceae produces butanol and 2,3-butanediol using anaerobic way. Additionally, Escherichia coli and other bacteria produce lactic and glyceric acids and dihydroacetone under microaerobic conditions. Succinic acid can be produced by aerobic and microaerobic pathways, while 1,3-propanediol and ethanol can be obtained by anaerobic and microaerobic conditions $[28,29,46,47]$.

Notwithstanding, there are some aggregate-value bioproducts that can be obtained from glycerin by biotechnological route. Although there are several works in the literature and patents, commercial initiatives are still rare. Some examples of industrial scale production are described below; however, there is no information about industrial initiatives in Brazil.

The chemical companies BASF and Cargill and industrial biotechnology company Novozymes are developing bio-based technologies to produce acrylic acid from renewable feedstocks. Currently, acrylic acid is produced by the oxidation of propylene derived from the refining of crude oil. Using biotechnology route, these companies have worked to develop microorganisms that can efficiently convert renewable feedstock, among them are glycerol, into 3-hydroxypropionic acid, which is one possible chemical precursor to acrylic acid [48]. The companies have carried out this precursor production in pilot scale, but they intend to increase for commercial scale still in 2014.

1,3-propanediol has showed to be a scientific and technological interest product. An Asia (METabolic EXplorer) and European initiatives (Propanergy and Glyfinery Projects) have been carried out to construct pilot and industrial plants to obtain this product from glycerin raw material. In all cases, the biotechnological route and the biorefinery concept are applied, including the production of biogas and other aggregated-value bioproducts. To develop the European projects, partnerships between private companies and universities were established [49-51].

Posada et al. [52] evaluated the conversion of raw glycerol to nine added-value products obtained by chemical (synthesis gas, acrolein, and 1,2-propanediol) or biochemical (ethanol, 1,3-propanediol, lactic acid, succinic acid, propionic acid, and poly-3-hydroxybutyrate) routes. The results showed that not only quality requirements were successfully reached but that all the processes were profitable. More income can be earned from 1,3-propanediol and 1,2-propanediol production, while less income would be obtained from hydrogen (synthesis gas) and succinic acid.

According to recent analysis of technical papers, the most studied chemical products obtained from glycerin are 1,3-propanediol, hydrogen, and propylene glycol. On the other hand, propylene glycol, acrolein, and dichlorohydrin were the most cited chemical products in patents.
Additionally, the main chemicals obtained from operating plants are propylene glycol and epichlorohydrin [53].

In this context, if glycerin is used in Brazil or worldwide as raw material for the production of fuels and value-added products in the glycerol biorefinery concept, it could increase balance of trade through the sale of these products, and it can prevent the accumulation of glycerin in companies when exports are unfavorable.

\section{Conclusions}

Brazil stands out on using biomass as an energy source. In addition, many raw materials have great potential for use in biorefineries. Among these raw materials are oilseeds such as soybeans, besides forest biomass, sugar cane and other biomass. Considering the availability of these raw materials and favorable conditions of price and costs, the results showed significant opportunities that can be exploited in Brazil in the biorefinery concept.

Soybean oil is the main raw material used in the production of biodiesel in Brazil. Despite increased use of biomass of soybean in the Brazilian energy matrix, petroleum products remain the most economically viable. The cost of production of soybean biodiesel in Brazil (US $\$ 1.25 / \mathrm{L}$ ) is well above the values of the production cost of diesel (US\$0.26/L). This is certainly a challenging factor that encourages the consolidation of biorefineries in Brazil. Besides biodiesel from soybean oil, the application of the biorefinery concept aimed the production of a wide range of products. The production of chemicals and biofuels from glycerin biodiesel byproduct is one of the main challenges within the concept of biorefinery. Some products as polyols, organic acids, alcohols, syngas, and biogas could be obtained from this industry that could be called 'glycerol biorefinery'.

Both biochemical and chemical route, including thermochemical processes, are essential and complementary in a biorefinery. It is not yet possible to define the best technologies and products for oleaginous chains that are under development, but at the present time, all of them must be considered. The possible combinations of raw materials, conversion/technology processes, and final products are practically unlimited in the biorefinery concept.

\section{Competing interests}

The authors declare that they have no competing interests.

\section{Authors' contributions}

MCTD and ELS wrote the Abstract and the 'Introduction' and 'Raw materials for biodiesel production' sections. DTS wrote the section 'Prices and costs of soybean biodiesel'. All authors participated in the writing of 'Challenges and opportunities within the concept of glycerol biorefinery' and the 'Conclusions' sections. All authors read and approved the final manuscript. 


\section{Acknowledgements}

We would like to thank Maria Goreti Braga for the graphical abstract design and José Manuel Cabral de Sousa Dias for the critical text review. This work was supported by grants from the Brazilian Agricultural Research Corporation (Embrapa) and Brazilian National Council for Scientific and Technological Development (CNPq).

\section{Received: 1 April 2014 Accepted: 1 July 2014 \\ Published online: 23 August 2014}

\section{References}

1. Brazilian Energy Balance (2013) Year 2102 / Empresa de Pesquisa Energética. EPE, Rio de Janeiro. https://ben.epe.gov.br/downloads/ Relatorio_Final_BEN_2013.pdf. Accessed 18 Feb 2014

2. King D, Inderwildi OR, Williams A, Hagan A (2010) The future of industrial biorefineries. World Economic Forum, Geneva. http://www3.weforum.org/docs/ WEF_FuturelndustrialBiorefineries_Report_2010.pdf. Accessed 18 Feb 2014

3. Publications IEA Bioenergy Task 42 Biorefinery. http://www.iea-bioenergy.task42biorefineries.com/upload_mm/5/8/2/a47bd297-2ace-44d0-

92bbcb7cc02f75de_Brochure_Totaal_definitief_webs.pdf. Accessed 18 Feb 2014

4. Pousa GPAG, Santos ALF, Suarez PAZ (2007) History and policy of biodiesel in Brazil. Energy Policy 35:5393-5398

5. ANP Monthly Bulletin of Biodiesel. http://www.anp.gov.br/?dw=65297. Accessed 10 Feb 2014

6. OECD-FAO Agricultural Outlook. http://stats.oecd.org/viewhtml.aspx?Quer$\mathrm{yld}=36356 \& \mathrm{vh}=0000 \& \mathrm{vf}=0 \&|\& i|=b l a n k \& l a n g=e m$. Accessed 19 Feb 2014

7. Geris R, Santos NAC, Amaral BA, Maia IDS, Castro VD, Carvalho JRM (2007) Biodiesel de soja: reação de transesterificação para aulas práticas de química orgânica. Quim Nova 30:1369-1373

8. Laviola BG, Alves AA (2011) Matérias-primas oleaginosas para biorrefinarias. In: Vaz S, Jr (ed) Biorrefinarias: cenários e perspectivas, vol 1. Embrapa Agroenergia, Brazil

9. IBGE Produção Agrícola Municipal. http://www.sidra.ibge.gov.br/bda/tabela/ listabl.asp? $c=1612 \& z=p \& o=18$. Accessed 19 Feb 2014

10. Conab Acompanhamento da Safra Brasileira. http://www.conab.gov.br/ OlalaCMS/uploads/arquivos/12_01_10_10_53_02_boletim_graos_40_ levantamento.pdf. Accessed 19 Feb 2014

11. Garcia S http://pecuaria.ruralbr.com.br/noticia/2012/02/sebo-bovino-ealternativa-viavel-para-producao-debiodiesel-3670782.html. Accessed 19 Feb 2014

12. APROSOJA. http://www.aprosoja.com.br. Accessed 19 Feb 2014

13. ANP Monthly bulletin of biodiesel. National Agency of Petroleum, Natural Gas and Biofuels, Rio de Janeiro

14. ANP. http://www.anp.gov.br/?dw=61225. Accessed 19 Feb 2014

15. ANP Preços nominais do biodiesel. http://www.anp.gov.br/?dw=67024 Accessed 19 Feb 2014

16. ABIOVE Estatística mensal do complexo soja. http://www.abiove.org.br/site/ index.php?page =estatistica\&area $=\mathrm{NCOyLTE}=$. Accessed 19 Feb 2014

17. NETO S A R Biodiesel. http://conab.gov.br/OlalaCMS/uploads/arquivos/11_04_11_ 08_45_49_conjuntura_biodisel_marco_2011..pdf. Accessed 19 Feb 2014

18. Caetano $\mathrm{M}$ Preço do biodiesel é o menor desde o início da mistura obrigatória. Valor Econômico, 04 /11/2013. http://www.valor.com.br/agro/ 3327022/preco-do-biodiesel-e-o-menor-desde-o-inicio-da-misturaobrigatoria. Accessed 19 Feb 2014

19. Cavalett O (2008) Análise do ciclo de vida da soja. In: PhD Thesis. Department of Food Engineering, Universidade Estadual de Campinas, SP, Brazil

20. LIMA AAS (2013) Viabilidade técnico-econômica da produção de biodiesel via rota alcalina e supercrítica baseadas em óleo residual. In: Masters Thesis Department of Chemical Engineering, Universidade Federal do Ceará, Fortaleza, CE, Brazil

21. Jonhson DT, Taconi KA (2007) The glycerin glut: options for the value-added conversion of crude glycerol resulting from biodiesel production. Environ Prog 26:338-348

22. Beatriz A, Araújo YJK, Lima DP (2011) Glicerol: um breve histórico e aplicação em sínteses estereosseletivas. Quim Nova 34:306-319

23. Mota CJA, Silva CXA, Gonçalves VLC (2009) Gliceroquímica: novos produtos e processos a partir da glicerina de produção de biodiesel. Quim Nova 32:639-648

24. Li Y, Reeder R (2011) Turning crude glycerin into polyurethane foam and biopolyols. In: Agriculture and Natural Resources Fact Sheet. The Ohio State University, Wooster, OH, USA [http://ohioline.osu.edu/aex-fact/pdf/0654.pdf]
25. Parente $\mathrm{E}_{1} \mathrm{Jr}$ Resíduos bem-vindos. [http://revistapesquisa.fapesp.br/2012/ 06/14/residuos-bem-vindos]

26. BiodieselBR. [http://www.biodieselbr.com/noticias/usinas/glicerina/ exportacoes-glicerina-us-54-mi-fevereiro-120313.htm]

27. (2013) BiodieselBR. [http://www.biodieselbr.com/noticias/usinas/glicerina/ exportacoes-glicerina-caem-45-marco-150413.htm]

28. Choi WJ (2008) Glycerol-based biorefinery for fuels and chemicals. Recent Pat Biotechnol 2:173-180

29. Almeida JR, Fávaro LC, Quirino BF (2012) Biodiesel biorefinery: opportunities and challenges for microbial production of fuels and chemicals from glycerol waste. Biotechnol Biofuels 5:1-48

30. Leoneti AB, Aragão-Leoneti V, Valle S, Oliveira WB (2012) Alternatives for the use of unrefined glycerol. Renew Energy 45:138-145

31. Fan XO, Burton R, Zhou Y (2010) Glycerol - byproduct of biodiesel production as a source for fuels and chemicals. Open Fuels Energy Sci J 3:17-22

32. Pachauri N, He B (2006) Value-added utilization of crude glycerol from biodiesel production: a survey of current research activities. In: Proceedings of the ASABE Annual International Meeting. American Society of Agricultural and Biological Engineers, Portland

33. Bozell JJ, Petersenb GR (2010) Technology development for the production of biobased products from biorefinery carbohydrates - the US Department of Energy's "Top 10" revisited. Green Chem 12:525-728

34. Pagliaro M, Ciriminna R, Kimura H, Rossi M, Della Pina C (2007) From glycerol to value-added product. Angew Chem Int Ed 46:4434-4440

35. Katryniok B, Paul S, Dumeignil F (2013) Recent developments in the field of catalytic dehydration of glycerol to acrolein. ACS Catal 3:1819-1834

36. Zhou CHC, Beltramini JN, Fan YX, Lu GQM (2008) Chemoselective catalytic conversion of glycerol as biorenewable source to valuable commodity chemicals. Chem Soc Rev 37:527-549

37. Adhikari S, Fernando SD, Haryanto A (2008) Hydrogen production from glycerin by steam reforming over nickel catalysts. Renew Energy 33:1097-1100

38. Gil S, Cuenca N, Romero A, Valverde JL, Sáchez-Silva L (2014) Optimization of the synthesis procedure of microparticles containing gold for the selective oxidation of glycerol. Appl Catal A 2014(472):11-20

39. Arco Chemical Technology, Kesling LP, Jr HS, Karas LJ, Liotta FJ Diesel fuel. Patent. Int. Cl. C10L 1/00. US5308365. 31/08/1993, 03/05/1994

40. Avasthi KS, Reddy RN, Patel S (2013) Challenges in the production of hydrogen from glycerol-a biodiesel byproduct via steam reforming process. Procedia Eng 51:423-429

41. Alonso DM, Bond JQ, Dumesic JA (2010) Catalytic conversion of biomass to biofuels. Green Chem 12:1493-1513

42. Spath PL, Dayton DC Preliminary screening - technical and economic assessment of synthesis gas to fuels and chemicals with emphasis on the potential for biomass-derived syngas. [http://www.nrel.gov/docs/fy04osti/ 34929.pdf]

43. Solvay to build bio-based epichlorohydrin plant in China to serve largest market in the world. [http://www.solvay.com/en/media/press_releases/ 20120611-epicerol-china.html]

44. Vinythai company profile. [http://www.solvayplastics.com/sites/ solvayplastics/EN/vinyls/Vinythai/Pages/CompanyProfile.aspx]

45. Bell BM, Briggs JR, Campbell RM, Chambers SM, Gaarenstroom PD, Hippler JG, Hook BD, Kearns H, Kenney JM, Kruper WJ, Schreck DJ, Theriault CN, Wolfe CP (2008) Glycerin as renewable feedstock for epichlorohydrin production. The GTE process. Clean 36:657-661

46. Abad S, Turon X (2012) Valorization of biodiesel derived glycerol as a carbon source to obtain added-value metabolites: focus on polyunsaturated fatty acids. Biotechnol Adv 30:733-741

47. Biebl H, Menzel K, Zeng AP, Deckwer WD (1999) Microbial production of 1,3-propanediol. Appl Microbiol Biotechnol 52:289-297

48. BASF, Cargill and Novozymes target commercial bio-based acrylic acid process. [http://www.basf.com/group/pressrelease/P-12-363]

49. METABOLIC EXPLORER: METabolic EXplorer announces start-up of industrialscale pilot. [http://www.euroinvestor.com/news/2009/12/14/metabolic-explorer-metabolic-explorer-announces-start-up-of-industrial-scale-pilot/ 10786665]

50. Periodic report summary 2 - PROPANERGY (integrated bioconversion of glycerine into value-added products and biogas at pilot plant scale). [http://cordis.europa.eu/result/rcn/53625_en.html]

51. GLYFINERY: sustainable and integrated production of liquid biofuels, green chemicals and bioenergy from glycerol in biorefineries. [https://www.ifeu. de/landwirtschaft/pdf/glyfinery_theparliamentmagazine_march2010.pdf] 
52. Posada JA, Rincón LE, Cardona CA (2012) Design and analysis of biorefineries based on raw glycerol: addressing the glycerol problem. Bioresour Technol 111:282-293

53. Freitas ZS (2013) Glicerina como matéria-prima para a indústria-química: avaliação dos esforços de pesquisa e das iniciativas comerciais. Master Thesis. Escola de Química, Universidade Federal do Rio de Janeiro. Rio de Janeiro, RJ, Brazil

doi:10.1186/s40538-014-0007-z

Cite this article as: Schultz et al:: The glycerol biorefinery: a purpose for

Brazilian biodiesel production. Chemical and Biological Technologies in Agriculture 2014 1:7

Submit your manuscript to a SpringerOpen ${ }^{\circ}$ journal and benefit from:

- Convenient online submission

- Rigorous peer review

- Immediate publication on acceptance

- Open access: articles freely available online

- High visibility within the field

- Retaining the copyright to your article

Submit your next manuscript at $\gg$ springeropen.com 